\title{
Sustainability Reporting in International Hotel Chains*
}

\author{
Simona Franzoni**, Marie Avellino***
}

\begin{abstract}
The rise of stakeholder engagement and corporate social responsibility emphasizes the necessary integration of the economic, social and environmental aspects of business management. This is not only reflected by decisions, and behaviours, but also by the tools and methods of communicating business results. It has become apparent that there is a need for all relevant stakeholders to be provided with consistent and comprehensive information about how corporate social responsibility and sustainable performance are being achieved.

The paper aims to show the tools used by major international hotel chains for sustainability reporting; an analysis on the quality and quantity of content provided in such reports by tourism enterprises, in order to make appropriate judgments about communications and the potential for improvement.
\end{abstract}

Keywords: Sustainability; Reporting; Hotel Chains, Corporate Social Responsibility; Transparency; Tourism; Global Markets

\section{Communication of CSR and Sustainable Performance}

The adoption of corporate social responsibility (CSR) policies (Carroll, 1979; Elkington, 1997), sustainability orientation (Brundtland, 1987) and enhancement of the importance of stakeholder view (Freeman, 1984; Jacoby, 1973; Longstreth \& Kesenblum, 1973; Donaldsond \& Preston, 1995) and stakeholder engagement (Sloan, 2009) have promoted integration in organisations between the economic and social-environmental dimensions. These actions serve as drivers for the improvement of the collection of additional economic information which results in the provision of new data, aimed at ensuring coherence among governance choices, organisational conduct and sustainable performance (Carroll, 1999; Freeman et al., 2010; Harrison et al., 2015; Schaltegger et al., 2017; Salvioni \& Gennari, 2017).

The economic dimension remains just as important, given the focus on shareholder perception (Markowitz, 1952; Modigliani \& Miller, 1958; Sharpe, 1964; Friedman, 1970), but emphasis is given to the connections between economic variables and other performance factors, which are jointly instrumental in acquiring consent and trust in stakeholder relation management, where increasingly stakeholders request both social and environmental information (Daub, 2007). The concept of

\footnotetext{
${ }^{*}$ The Authors: Franzoni, S. $\S ~ 2,3$, Avellino, M. §§ 1, 4

** Associate Professor of Business Administration, University of Brescia (simona.franzoni@unibs.it)

*** Lecturer in Tourism, University of Malta (marie.avellino@um.edu.mt)
} 
accountability is one of the basic principles of the change process in both profit and non-profit organisations, and studies on this subject have underlined, over and over again, the aspect of "transparency", "responsibility", and "reporting aptitude".

Gray, Owen and Adams (1996) affirm that accountability represents "the duty to provide an account of the actions for which one is held responsible. In other words, accountability involves two responsibilities or duties: responsibility to undertake certain actions; responsibility to provide an account for those actions".

We therefore confirm the need to provide all relevant stakeholders with a uniform and complete set of information, through effective reporting that communicates how to exercise the responsibilities and the related economic, social and environmental results achieved overall.

We can infer from the above that reporting focusing solely on economic information is not sufficient to ensure full transparency of corporate governance and corporate responsibility towards stakeholders. The main international players have become increasingly interested in social-environmental reporting (United Nations Conference on Trade and Development, World Intellectual Capital Initiative, AccountAbility 1000, Global Reporting Initiative, International Integrated Reporting Council, Institute of Chartered Accountants, etc.). As well as of many studies (Gray et al., 1987; Gray et al. 1996; Cormier \& Gordon, 2001; Cerin, 2002; Eccles \& Krzus, 2010; Eccles \& Serafeim, 2011; Brondoni, 2003; Salvioni \& Astori, 2013; Brondoni, 2014; Salvioni \& Bosetti, 2014; Cantino \& Cortese, 2017) and regulations and financial market guidelines (Environmental, Social and Governance Reporting by London Stock Exchange Group; Directive 2014/95/EU, etc.).

The corresponding reporting with a focus on social and environmental information has benefited from documents such as: the sustainability report, the environmental report, CSR report, etc. In this regard, Gray (2002) believes that far from presenting substantial differences, the different names used are simply "labels" to pinpoint a phenomenon characterised by common specificities (Mathews, 1997; Hibbit, 2004).

However, if, on the one hand, the spread of reporting documentation has resulted in greater transparency of information, on the other, it has fragmented the information and at times generated an abundance of information, consequently making it difficult to perform an integrated review of the organisation's performance, to meet the requirement of conciseness, and to easily reach the information.

We therefore see a growing need not only to disseminate, but also to supplement information, in order to understand how performance is generated, corporate efforts to pursue it and future orientation to attain satisfactory levels of sustainability. The process to improve integration between the various result areas and the consolidation of interdependency among economic, social and environmental dimensions are reflected in the preparation of one corporate report to ensure interpretation of corporate performance and the ability of an organisation to create value over time and to meet the stakeholders' knowledge expectations.

The Global Reporting Initiative (GRI) Standards represent global best practice for reporting publicly on a range of economic, environmental and social impacts. Sustainability reporting based on the standards provides information about an organization's positive or negative contributions to sustainable development.

The UN 2030 Agenda for Sustainable Development and its 17 Sustainable Development Goals (SDGs) and 169 targets came into force on the 1 January 2016. 
Goal 12 is to "Ensure sustainable consumption and production patterns", and in particular, 12.6 target shows that the state members should "encourage companies, especially large and transnational companies, to adopt sustainable practices and to integrate sustainability information into their reporting cycle". The success of this goal will be measured by the "Number of companies publishing sustainability reports" (SDG 12.6.1).

The World Tourism Organization recognizes that tourism has the potential to contribute to all the 17 Sustainable Development Goals proposed by the $2030 \mathrm{UN}$ Agenda for Sustainable Development (Rifai, 2017), but more specifically according to the Chengdu Declaration (2017) to SDGs 8 (decent work and economic growth), 12 (responsible consumption and production) and 14 (life below water) The correct management of tourist firms takes on particular importance in the sustainable development. Indeed, it is necessary to move towards a progressive balance that must simultaneously satisfy the needs for economic growth and the consumption of the area's natural resources, for the benefit of quality of life and sustainable development. Since the end of the 80's, leading scientific literature has dedicated attention to this issue (Hunter \& Green, 1995; Hunter, 1997; Butler, 1999; Hardy et al., 2002; Liu, 2003; Holcomb et al., 2007; Buckley, 2012, Sloan, 2012; Jankovic \& Krivaeic, 2014; Franzoni, 2015; Guix, 2018).

In summary, to ensure sustainable development means bringing together, in a long term vision, the balance of three dimensions: social, environmental, economic. All operators in the tourism sector, in particular international hotel chains have a significant impact on sustainability (Masa'deh et. al., 2017), therefore the close interdependencies between these dimensions should be given due consideration.

The aim of this paper is to analyse the tools used by the main international hotel chains to report social responsibility and sustainable performance and how the organisations observed connect the (social, environmental, economic) information they provide in their reports, in order to express appropriate judgements on corporate communication and the relative potential for improvement.

\section{Type of Reporting in International Hotel Chains: an Empirical Research}

The objective of the research was to examine the type of reporting used by the main international hotel chains, analysing their content, in order to express suitable evaluations on the communication in the facilities and the relative potential for improvement.

The study was conducted using the content analysis technique. According to Neuman (2003), "content analysis is a technique for gathering and analysing the content of text. The content refers to words, meanings, pictures, symbols, ideas, themes, or any message that can be communicated". The manual method of reading was used to analyse the documents available online for the selected firms. Therefore, dedicated tables were prepared, containing the items grouped. The contents sought in the reports of the hotel facilities analysed are the items, according to Global Reporting Initiatives (GRI) guidelines, summarised in Table 1. The tables were filled in for each organisation. 
Table 1: Items Identified to Analyse the Type of Contents Available

\begin{tabular}{ll} 
Type of indicators & Single items \\
& $\begin{array}{l}\text { Direct economic value generated and distributed; Financial implications } \\
\text { and other risks and opportunities for the organization's activities due to } \\
\text { climate change; Coverage of the organization's defined benefit plan } \\
\text { obligations; Financial assistance received from government; Development } \\
\text { and impact of infrastructure investments and services supported; } \\
\text { Significant indirect economic impacts, including the extent of impacts. }\end{array}$ \\
\hline & Energy consumption within the organization; Energy intensity; Reduction \\
& of energy consumption; Total water withdrawal by source; Percentage and \\
& total volume of water recycled and reused; Description of significant \\
& impacts of activities, products, and services on biodiversity in protected \\
& areas and areas of high biodiversity value outside protected areas; Direct \\
greenhouse gas emissions; Energy indirect greenhouse gas emissions; & Greenhouse gas emissions intensity; Reduction of greenhouse gas \\
emissions; Emissions of ozone-depleting substances; Total weight of waste \\
by type and disposal method; Weight of transported, imported, exported, or \\
treated waste deemed hazardous under the terms of the basel convention 2 \\
annex i, ii, iii, and viii, and percentage of transported waste shipped \\
internationally; Percentage of new suppliers that were screened using \\
environmental criteria.
\end{tabular}

Total number and rates of new employee hires and employee turnover by age group, gender and region; Type of injury and rates of injury, occupational diseases, lost days, and absenteeism, and total number of work-related fatalities, by region and by gender; Workers with high incidence or high risk of diseases related to their occupation; Average hours of training per year per employee by gender, and by employee category; Composition of governance bodies and breakdown of employees per employee category according to gender, age group, minority group membership, and other indicators of diversity; Operations and suppliers identified as having significant risk for incidents of child labor, and measures taken to contribute to the effective abolition of child labor; Operations and suppliers identified as having significant risk for incidents of forced or compulsory labor, and measures to contribute to the

Social elimination of all forms of forced or compulsory labor; Percentage of operations with implemented local community engagement, impact assessments, and development programs; Operations with significant actual and potential negative impacts on local communities; Total number and percentage of operations assessed for risks related to corruption and the significant risks identified; Communication and training on anti-corruption policies and procedures; Percentage of significant product and service categories for which health and safety impacts are assessed for improvement; Total number of incidents of non-compliance with regulations and voluntary codes concerning the health and safety impacts of products and services during their life cycle, by type of outcomes; Results of surveys measuring customer satisfaction; Total number of substantiated complaints regarding breaches of customer privacy and losses of customer data.

Source: Global Reporting Initiative guidelines (2016). 
The companies analysed represent the top ten hotel chains as listed in hotels magazine. This is an annual listing composed by Hotels magazine (official publication of the International Hotel and Restaurant Association), it compares the top ten hotel companies on specified metrics.

The hotels are shown in Table 2 and make up the global top ten for the number of rooms available.

Table 2: The Companies Analysed

\begin{tabular}{cllrr}
\hline $\begin{array}{c}\mathbf{2 0 1 7} \\
\text { rank }\end{array}$ & \multicolumn{1}{c}{ Hotel Chains } & \multicolumn{1}{c}{ Location } & \multicolumn{1}{c}{$\begin{array}{c}\mathbf{2 0 1 7} \\
\text { Rooms }\end{array}$} & $\begin{array}{c}\text { 2017 } \\
\text { Hotels }\end{array}$ \\
\hline 1 & Marriott International & Bethesda, Maryland USA & $1,195,141$ & 6,333 \\
\hline 2 & Hilton & Mclean, Virginia USA & 856,115 & 5,284 \\
\hline 3 & $\begin{array}{l}\text { IHG (InterContinental } \\
\text { Hotels Group) }\end{array}$ & $\begin{array}{l}\text { Denham, Buckinghamshire, } \\
\text { England }\end{array}$ & 798,075 & 5,348 \\
\hline 4 & Wyndham Hotel Group & Parsippany, New Jersey USA & 753,161 & 8,643 \\
\hline 5 & $\begin{array}{l}\text { Shanghai Kin Jiang } \\
\text { International Hotel Group } \\
\text { Co. }\end{array}$ & Shanghai, China & 689,111 & 6,794 \\
& AccorHotels & Paris, France & & \\
\hline 7 & $\begin{array}{l}\text { Choice Hotels } \\
\text { International }\end{array}$ & Rockville, Maryland USA & 616,181 & 4,283 \\
\hline 8 & $\begin{array}{l}\text { BTG Homeinns Hotels } \\
\text { (Group) Co. }\end{array}$ & Beijing, China & 521,335 & 6,815 \\
\hline 9 & China Lodging Group & Shanghai, China & 383,743 & 3,712 \\
\hline 10 & $\begin{array}{l}\text { Best Western Hotels \& } \\
\text { Resorts }\end{array}$ & Phoenix, Arizona USA & 379,675 & 3,746 \\
\hline
\end{tabular}

Source: Hotels magazine (2018).

The reports published on the website of the 10 hotel chains considered is shown in Table 3. These reports mainly apply to the last reporting year, highlighting economic, social and environmental performance.

In this stage, we encounter various terms used in reports to present social and environmental information: Sustainability and Social Impact Report, Corporate Responsibility Report, Responsible Business Report, Environmental, Social and Governance Report, etc. For the sake of convenience, we will only use one term, Sustainability Report (SR), from now on, to refer to that group of documents.

With regard to the documents available, if we consider the 10 hotel chains for which documentation download was possible, 4 organisations do not publish online any documents applicable to sustainability or corporate responsibility, 2 organisation do not have a dedicated section on their websites and 2 organisation do not have a complete section on their websites.

The remaining 6 organisations published both reports and all have a dedicated section on their website. In general, the other organisations with a dedicated section tend to publish online the same information as provided in their reports that we analysed.

The results of the investigation are presented below. 
Table 3: Reporting Types

\begin{tabular}{|c|c|c|c|c|}
\hline No. & Hotel Chains & Reporting types & Year & Guidelines \\
\hline 1 & Marriott International & $\begin{array}{l}\text { Sustainability and } \\
\text { Social impact report }\end{array}$ & 2017 & $\begin{array}{l}\text { Global Reporting } \\
\text { Initiative (GRI) } \\
\text { Standards }\end{array}$ \\
\hline 2 & Hilton & $\begin{array}{l}\text { Corporate } \\
\text { Responsibility Report }\end{array}$ & 2017 & $\begin{array}{l}\text { Global Reporting } \\
\text { Initiative (GRI) } \\
\text { Standards }\end{array}$ \\
\hline 3 & $\begin{array}{l}\text { IHG (InterContinental } \\
\text { Hotels Group) }\end{array}$ & $\begin{array}{l}\text { Responsible Business } \\
\text { Report }\end{array}$ & 2017 & GRI G4 \\
\hline 4 & Wyndham Hotel Group & $\begin{array}{l}\text { Corporate Social } \\
\text { Responsibility Report }\end{array}$ & $\begin{array}{l}2016- \\
2017\end{array}$ & GRI G4 \\
\hline 5 & $\begin{array}{l}\text { Shanghai Kin Jiang } \\
\text { International Hotel Group } \\
\text { Co. }\end{array}$ & $\begin{array}{l}\text { Environmental social } \\
\text { and governance } \\
\text { report/Annual Report }\end{array}$ & 2017 & $\begin{array}{l}\text { Environmental, social } \\
\text { and governance } \\
\text { reporting guide (ESG } \\
\text { Guide) }\end{array}$ \\
\hline 6 & AccorHotels & GRI Standards & 2017 & $\begin{array}{l}\text { Global Reporting } \\
\text { Initiative (GRI) } \\
\text { Standards } \\
\end{array}$ \\
\hline 7 & $\begin{array}{l}\text { Choice Hotels } \\
\text { International }(*)\end{array}$ & & & \\
\hline 8 & $\begin{array}{l}\text { BTG Homeinns Hotels } \\
\text { (Group) Co. }\end{array}$ & & & \\
\hline 9 & China Lodging Group & & & \\
\hline 10 & $\begin{array}{l}\text { Best Western Hotels \& } \\
\text { Resorts (*) }\end{array}$ & & & \\
\hline
\end{tabular}

(*) Some "corporate social responsibility" information is available only on website.

\section{The Economic, Environmental and Social Contents of the Hotel Chain Reports}

The research involved analysing the content of the 6 available reports, differentiating between information aimed at summarising: economic, environmental and social dimensions.

The analysis carried out allowed us to understand how the hotel chains operate in the field of sustainability reporting, but above all it has allowed us to highlight the gaps that some of them still have.

Table 4: Economic, Environmental and Social Contents

\begin{tabular}{lc}
\hline \multicolumn{1}{c}{ Type of indicators } & \multicolumn{1}{c}{$\begin{array}{c}\text { No. Hotel } \\
\text { Chains }\end{array}$} \\
\hline \multicolumn{1}{c}{ ECONOMIC INDICATORS } & 4 \\
\hline $\begin{array}{l}\text { Direct economic value generated and distributed } \\
\text { Financial implications and other risks and opportunities for the organization's } \\
\text { activities due to climate change }\end{array}$ & 5 \\
$\begin{array}{l}\text { Coverage of the organization's defined benefit plan obligations } \\
\text { Financial assistance received from government }\end{array}$ & 3 \\
\hline
\end{tabular}


Development and impact of infrastructure investments and services supported

Significant indirect economic impacts, including the extent of impacts

\begin{tabular}{ll}
\hline \multicolumn{1}{c}{ ENVIRONMENTAL INDICATORS } & 6 \\
\hline Energy consumption within the organization & 5 \\
Energy intensity & 5 \\
Reduction of energy consumption & 5 \\
Total water withdrawal by source & 4 \\
Percentage and total volume of water recycled and reused & 3 \\
Description of significant impacts of activities, products, and services on & \\
biodiversity in protected areas and areas of high biodiversity value outside & \\
protected areas & 5 \\
Direct greenhouse gas (ghg) emissions & 5 \\
Energy indirect greenhouse gas (ghg) emissions & 5 \\
Greenhouse gas (ghg) emissions intensity & 5 \\
Reduction of greenhouse gas (ghg) emissions & 1 \\
Emissions of ozone-depleting substances & 5 \\
Total weight of waste by type and disposal method & \\
Weight of transported, imported, exported, or treated waste deemed hazardous and & 1 \\
percentage of transported waste shipped internationally & \\
Percentage of new suppliers that were screened using environmental criteria & 4 \\
\hline
\end{tabular}

\section{SOCIAL INDICATORS}

Total number and rates of new employee hires and employee turnover by age group, gender and region

Type of injury and rates of injury, occupational diseases, lost days, and absenteeism, and total number of work-related fatalities, by region and by gender

Workers with high incidence or high risk of diseases related to their occupation

Average hours of training per year per employee by gender, and by employee category

Composition of governance bodies and breakdown of employees per employee category according to gender, age group, minority group membership, and other indicators of diversity

Operations and suppliers identified as having significant risk for incidents of child labor, and measures taken to contribute to the effective abolition of child labor Operations and suppliers identified as having significant risk for incidents of forced or compulsory labor, and measures to contribute to the elimination of all forms of forced or compulsory labor

Percentage of operations with implemented local community engagement, impact assessments, and development programs

Operations with significant actual and potential negative impacts on local communities

Total number and percentage of operations assessed for risks related to corruption and the significant risks identified

Communication and training on anti-corruption policies and procedures

Percentage of significant product and service categories for which health and safety impacts are assessed for improvement

Total number of incidents of non-compliance with regulations and voluntary codes concerning the health and safety impacts of products and services during their life cycle, by type of outcomes

Results of surveys measuring customer satisfaction

Total number of substantiated complaints regarding breaches of customer privacy and losses of customer data 
With reference to the three dimensions analysed, we note:

- economic indicators: almost all the chains take into account three or four of these, with the exception of 1 of 6 organisations examined which only considers one, and the Chinese hotel chain does not show any economic indicator;

- environmental indicators: all hotel chains have focused more on indicators concerning energy, water, emissions and waste. Only 3 of 6 companies take into account the biodiversity indicator and the indicator on the supplier's environmental assessment;

- social indicators: those considered by all hotel chains are those related to employment, education and training, diversity and equal opportunities, local community. 1 of 6 hotel chains analysed take into account almost all the highlighted indicators.

Finally, just 1 organisation highlights the spread of the revenues among the main stakeholder and the relationship between the CSR and sustainable initiatives pursued by the organisation and the positive impact generated thanks to the linkage of economic (increased revenue and corporate profitability), environmental (cutting of costs associated with energy, waste, etc.) and social (improved reputation and customer satisfaction) performance.

It is found that many of the hotel chains analysed in the sustainability reports refer to the UN Agenda 2030 and this shows the intense interest of the same towards this issue.

The issue of sustainability communication analysed so far concerns the tourism sector and the main hotel chains. It is clear that this issue is actually more complex and involves more players. However, the contribution, that so large and widespread hotels in the world can give, is relevant and decisive. The information provided allows us to understand how hotel chains are moving to achieve sustainable results, and tourists can make informed decisions when selecting hotels that are oriented towards sustainability.

\section{Conclusions and Emerging Issues}

The results showed that these hotels could improve their reporting, by reinforcing the contents and the respective integrations in order to clearly show how the information is linked and how the organisation creates value over time.

It is not positive that 4 of the 10 companies analysed have not published online any corporate reports. We also note that 2 of the 10 chains do not dedicate any section or provide incomplete sections of their website to CSR and Sustainability.

Undoubtedly, sustainability reporting is a voluntary task. Each firm takes on methods and tools to report its sustainable performance. The introduction of internationally recognised reporting models, as well as regulations and financial market guidelines, should guide firms to improve their transparency, in particular with respect to sustainability reporting. The dissemination of a culture of transparency, although gradual, will be a "requried" step for an improved effectiveness of communication and a reinforcement of stakeholders' trust. 
This analysis strongly receommends that hotels need to make improvements in their reporting, considering their importance in the tourism sector and in the economic, social and environmental context worldwide. Compared to other sectors of the economy, research on sustainability reporting in hospitality is scant, and further indepth investigation and studies are indispensable if we are to measure the progress to reach the 2030 Development Goals.

It must be stressed that the study conducted has limitations, considering the small sample size of companies observed. Moreover, corporate information changes continuously and the observation is based mainly on static reports and not dynamic reports (Bosetti, 2018) published on the institutional website of the companies.

Moreover, the existence of a globally accepted reporting model does not guarantee the substantial efficacy of corporate reporting. This depends on the adoption of reliability and transparency approaches which require a strong corporate culture, based on shared values of responsibility and transparency aimed at meeting the knowledge and assessment needs of stakeholders and encouraging key stakeholders to take part and cooperate to create value in the short, medium and long term.

\section{Bibliography}

Bosetti, L. (2018). Web-Based Integrated CSR Reporting: An Empirical Analysis, Symphonya. Emerging Issues in Management (symphonya.unimib.it), (1), 18-38. http://dx.doi.org/10.4468/2018.1.02bosetti

Brondoni, S. M. (2003). Network Culture, Performance \& Corporate Responsibility, Symphonya. Emerging Issues in Management (symphonya.unimib.it), (1), 8-24.

http://dx.doi.org/10.4468/2003.1.02brondoni

Brondoni, S. M. (2014). Global Capitalism and Sustainable Growth. From Global Products to Network Globalisation. Symphonya. Emerging Issues in Management (symphonya.unimib.it) (1), 10-31.

http://dx.doi.org/10.4468/2014.1.02brondoni

Brundtland, G (1987). Our Common Future: Report of the 1987 World Commission on Environment and Development, Oxford: Oxford University Press.

Buckley, R. (2012). Sustainable Tourism: Research and Reality, Annals of Tourism Research, 39(2), 528-546.

http://dx.doi.org/10.1016/j.annals.2012.02.003

Butler, R. W. (1999). Sustainable Tourism. A State of the Art Review, Tourism Geographies, 1(1), 725.

http://dx.doi.org/10.1080/14616689908721291

Cantino, V., \& Cortese, D. (2017). Integrated Report System: Purposes and Benefits of the Italian Law, Symphonya. Emerging Issues in Management (symphonya.unimib.it), (1), 83-94.

http://dx.doi.org/10.4468/2017.1.07cantino.cortese

Carroll, A. B. (1979). A Three-Dimensional Conceptual Model of Corporate Performance, Academy of Management Review, 4(4), 497-505.

http://dx.doi.org/10.2307/257850

Carroll, A. B. (1999). Corporate Social Responsibility: Evolution of a Definitional Construct, Business and Society Review, 38(3), 268-295. 
Carroll, A. B., \& Buchholtz, A. K. (2006). Business and Society: Ethics and Stakeholder Management, Thompson Publishing Group, Ohio.

Cerin, P. (2002). Communication in Corporate Environmental Reports, Corporate Social Responsibility and Environmental Management, 9(1), 46-66.

http://dx.doi.org/10.1002/csr.6

Cormier, D., \& Gordon, I. M. (2001). An Examination of Social and Environmental Reporting Strategies. Accounting Auditing and Accountability Journal, 14(5), 587-616.

http://dx.doi.org/10.1108/EUM0000000006264

Daub, C. H. (2007). Assessing the Quality of Sustainability Reporting: An Alternative Methodological Approach, Journal of Cleaner Production, 15(1), 75-85.

http://dx.doi.org/10.1016/j.jclepro.2005.08.013

Directive 2014/95/EU of the European Parliament and of the Council of 22 October 2014 amending Directive 2013/34/EU as regards disclosure of non-financial and diversity information by certain large undertakings and groups Text with EEA relevance. European Commission.

Donaldson, T., \& Preston L. E. (1995). The Stakeholder Theory of the Corporation: Concepts, Evidence, and Implications. The Academy of Management Review, 20(1), 65-91.

http://dx.doi.org/10.2307/258887

Eccles, R. G., \& Krzus, M. P. (2010). One Report. Integrated Reporting for a Sustainable Strategy, John Wiley \& Sons, New Jersey.

Eccles, R. G., \& Serafeim, G. (2011). Accelerating the Adoption of Integrated Reporting, in De Leo, F. \& Vollbracht, M (eds.)., CSR Index 2011, InnoVatio Publishing Ltd., Boston.

Elkington, J. (1997). Cannibals with Forks: The Triple Bottom Line of 21st Century Business, Capstone, Oxford.

Franzoni, S. (2015). Measuring the Sustainability Performance of the Tourism Sector. Tourism Management Perspectives, (16), 22-27.

http://dx.doi.org/10.1016/j.tmp.2015.05.007

Freeman, R. E. (1984). Strategic Management: a Stakeholder Approach, Pitman Publishing, New York.

Freeman, R. E., Wicks, A., Harrison, J., Parmar, B., \& De Colle, S. (2010). Stakeholder Theory: The State of The Art, Cambridge University Press, Cambridge.

Friedman, M. (1970). The social responsibility of business is to increase its profits. N.Y. Times, 6(30), 126-127.

Gray, R. (2002). The Social Accounting Project and Accounting Organization and Society: Privileging Engagement, Imaginings, New Accountings and Pragmatism over Critique? Accounting, Organisation and Society, 27(7), 687-708.

http://dx.doi.org/10.1016/S0361-3682(00)00003-9

Gray, R., Owen, D. \& Adams, C. (1996). Accounting and Accountability: Changes and Challenge in Corporate Social and Environmental Reporting, Prentice-Hall, Hemel Hempstead.

Gray, R., Owen, D. \& Maunders, K. T. (1987). Corporate Social Reporting:Accounting and Accountability, Prentice-Hall, Hemel Hempstead.

GRI (2016), Sustainability Reporting Guidelines, Global Reporting Initiative.

Guix, M., Bonilla-Priego, M. J. \& Font, X. (2018). The Process of Sustainability Reporting in International Hotel Groups: An Analysis of Stakeholder Inclusiveness, Materiality and Responsiveness, Journal of Sustainable Tourism, 26(7), 1063-1084.

http://dx.doi.org/10.1080/09669582.2017.1410164

Hardy, A., Pearson, L., \& Beeton, R. (2002). Sustainable Tourism: Concept and its Position in Relation to Tourism Theory, Journal of Sustainable Tourism, 10(6), 476-496.

http://dx.doi.org/10.1080/09669580208667183 
Harrison, J., Freeman, R. E., \& Cavalcanti Sá de Abreu, M. (2015). Stakeholder Theory As an Ethical Approach to Effective Management: Applying the Theory to Multiple Contexts, Revista Brasileira e Gestão de Negócios. Review of Business Management, 17(55), 858-869.

Hibbit, C. (2004). External Environmental Disclosure and Reporting by Large European Companies, Limperg Institute, Amsterdam.

Holcomb, J. L., Upchurch, R. S., \& Okumus, F. (2007). Corporate Social Responsibility: What Are Top Hotel Companies Reporting? International Journal of Contemporary Hospitality Management, 19(6), 461-475.

http://dx.doi.org/10.1108/09596110710775129

Hunter, C. (1997). Sustainable Tourism as an Adaptive Paradigm, Annals of Tourism Research, 24(4), 850-867.

Hunter, C., \& Green, H. (1995). Tourism and the Environment: a Sustainable Relationship, Routledge, London.

International Integrated Reporting Council (2013). Integrated Reporting Framework, IIRC.

Jacoby, N. H. (1973). Corporate Power and Social Responsibility, Mac Millan, New York.

Jankovic, S. \& Krivaeic, D. (2014). Environmental Accounting as Perspective for Hotel Sustainability: Literature Review, Tourism and Hospitality Management, 20(1), 103-120.

Liu, Z. (2003). Sustainable Tourism Development: A Critique. Journal of Sustainable Tourism, 11(6), 459-475.

http://dx.doi.org/10.1080/09669580308667216

London Stock Exchange Group (2013). Environmental, Social and Governance Reporting, London.

Longstreth, B. \& Kesenblum D. (1973). Corporate Social Responsibility and the Institutional Investor, Praeger, New York.

Markowitz, H. M. (1952). Portfolio Selection. Journal of Finance, 7(1), 77-91.

Masa'deh, R., Nasseef, M. A., Sunna, C., Suliman, M., \& Albawab, M. (2017). The Effect of Hotel Development on Sustainable Tourism Development. International Journal of Business Administration, 8(4), 17-33.

http://dx.doi.org/10.5430/ijba.v8n4p16

Mathews, M. (1997). Twenty Five Years of Social and Environmental Accounting Research: Is There a Silver Jubilee to Celebrate. Accounting, Auditing and Accountability Journal, 10(4), 481-531. http://dx.doi.org/10.1108/EUM0000000004417

Modigliani, F., \& Miller, M. (1958). The Cost of Capital, Corporation Finance and the Theory of Investment. American Economic Review, 48(2), 261-297.

Neuman, W. (2003), Social Research Methods: Qualitative and Quantitative Approaches, Allyn \& Bacon, Boston.

Rifai, T. (2017). Tourism and Job Creation - Advancing the 2030 Development Agenda. http://reports. weforum.org/travel-and-tourism-competitiveness-report-2017/tourism-and-jobcreation-advancing-the-2030-development-agenda/

Salvioni, D. M., \& Astori, R. (2013). Sustainable Development and Global Responsibility in Corporate Governance, Symphonya. Emerging Issues in Management (symphonya.unimib.it), 1, 2852.

http://dx.doi.org/10.4468/2013.1.03salvioni.astori

Salvioni, D. M., \& Bosetti, L. (2014). Sustainable Development and Corporate Communication in Global Markets, Symphonya. Emerging Issues in Management (symphonya.unimib.it), 1, 32-51.

http://dx.doi.org/10.4468/2014.1.03salvioni.bosetti

Salvioni, D. M., \& Gennari F. (2017). CSR, Sustainable Value Creation and Shareholder Relations, Symphonya. Emerging Issues in Management (symphonya.unimib.it), (1), 36-49.

http://dx.doi.org/10.4468/2017.1.04 salvioni.gennari 
(c) SYMPHONYA Emerging Issues in Management, n. 1, 2019

symphonya.unicusano.it

Schaltegger, S., Hörisch, J., \& Freeman, R. E. (2017). Business Cases for Sustainability: A Stakeholder Theory Perspectiv, Organization \& Environment, 1-22.

http://dx.doi.org/10.1177/1086026617722882

Sharpe, W. F. (1964). Capital asset prices: A Theory of Market Equilibrium Under Conditions of Risk, Journal of Finance, 19(3), 425-442.

Sloan, P. (2009). Redefining Stakeholder Engagement, Journal of Corporate Citizenship, 36, 25-40.

Sloan, P., Legrand, W., \& Chen, J.S. (2012). Sustainability in the Hospitality Industry: Principles of Sustainable Operations, Routledge, Abingdon, Oxon.

Weinstein, J. (2018). Hotels Magazine, Chicago. 